\title{
Nitrate transporters in leaves and their potential roles in foliar uptake of nitrogen dioxide ${ }^{\dagger}$
}

\author{
Yanbo $\mathrm{Hu}^{1 *}$, Victoria Fernández ${ }^{2}$ and Ling $\mathbf{M a}^{3 *}$ \\ 1 College of Life Science, Northeast Forestry University, Harbin, China \\ 2 Forest Genetics and Ecophysiology Research Group, School of Forest Engineering, Technical University of Madrid, Madrid, Spain \\ ${ }^{3}$ School of Forestry, Northeast Forestry University, Harbin, China
}

Edited by:

Ebrahim Hadavi, Islamic Azad

University, Iran

Reviewed by:

Abdullahil Baque, Shere-Bangla

Agricultural University, Bangladesh

Brian Grout, University of

Copenhagen, Denmark

\section{*Correspondence:}

Yanbo Hu and Ling Ma, Northeast

Forestry University, 26 Hexing Road,

Xiangfang District, Harbin 150040,

P. R. China

e-mail: huybnefu@yahoo.com

${ }^{\dagger}$ This paper was dedicated to

Professor Hartmut K. Lichtenthaler

on the occasion of his 80th birthday.
While plant roots are specialized organs for the uptake and transport of water and nutrients, the absorption of gaseous or liquid mineral elements by aerial plant parts has been recognized since more than one century. Nitrogen $(\mathrm{N})$ is an essential macronutrient which generally absorbed either as nitrate $\left(\mathrm{NO}_{3}^{-}\right)$or ammonium $\left(\mathrm{NH}_{4}^{+}\right)$by plant roots. Gaseous nitrogen pollutants like $\mathrm{N}$ dioxide $\left(\mathrm{NO}_{2}\right)$ can also be absorbed by plant surfaces and assimilated via the $\mathrm{NO}_{3}^{-}$assimilation pathway. The subsequent $\mathrm{NO}_{3}^{-}$flux may induce or repress the expression of various $\mathrm{NO}_{3}^{-}$-responsive genes encoding for instance, the transmembrane transporters, $\mathrm{NO}_{3}^{-} / \mathrm{NO}_{2}^{-}$(nitrite) reductase, or assimilatory enzymes involved in $\mathrm{N}$ metabolism. Based on the existing information, the aim of this review was to theoretically analyze the potential link between foliar $\mathrm{NO}_{2}$ absorption and $\mathrm{N}$ transport and metabolism. For such purpose, an overview of the state of knowledge on the $\mathrm{NO}_{3}^{-}$transporter genes identified in leaves or shoots of various species and their roles for $\mathrm{NO}_{3}^{-}$transport across the tonoplast and plasma membrane, in addition to the process of phloem loading is briefly provided. It is assumed that a $\mathrm{NO}_{2}$-induced accumulation of $\mathrm{NO}_{3}^{-} / \mathrm{NO}_{2}^{-}$may alter the expression of such genes, hence linking transmembrane $\mathrm{NO}_{3}^{-}$transporters and foliar uptake of $\mathrm{NO}_{2}$. It is likely that NRT1/NRT2 gene expression and species-dependent apoplastic buffer capacity may be also related to the species-specific foliar $\mathrm{NO}_{2}$ uptake process. It is concluded that further work focusing on the expression of NRT1 (NRT1.1, NRT1.7, NRT1.11, and NRT1.12), NRT2 (NRT2.1, NRT2.4, and NRT2.5) and chloride channel family genes (CLCa and CLCd) may help us elucidate the physiological and metabolic response of plants fumigated with $\mathrm{NO}_{2}$.

Keywords: chloride channel gene, nitrate reductase, nitrate transporter, nitrogen dioxide, signal transmission

\section{INTRODUCTION}

Nitrate $\left(\mathrm{NO}_{3}^{-}\right)$is the most common form of nitrogen used by plants for growth and development (Bertoni, 2012). Despite the major role of plant roots is absorbing and transporting water and mineral elements, there is abundant evidence showing that nutrients can also be taken up by aerial plant parts (e.g., leaves, fruits and stems) (Eichert and Fernández, 2012; Fernández and Brown, 2013). Foliar applied $\mathrm{NO}_{3}^{-}$may be absorbed and assimilated efficiently as shown in several studies carried out with different plant species (e.g., Stiegler et al., 2011; Uscola et al., 2014). Gaseous air pollutants like nitrogen dioxide $\left(\mathrm{NO}_{2}\right)$ can also be deposited into plant leaves and be taken up mainly through stomata (Eichert and Fernández, 2012). $\mathrm{NO}_{2}$ molecules may dissolve in the aqueous phase of the apoplastic space being consequently transformed into nitrate $\left(\mathrm{NO}_{3}^{-}\right)$and/or nitrite $\left(\mathrm{NO}_{2}^{-}\right)$by chemical reactions. Thereafter, $\mathrm{NO}_{2}$-derived $\mathrm{NO}_{3}^{-}$may be transported across the plasma membrane by $\mathrm{NO}_{3}^{-}$transporters and reach the cytoplasm for further incorporation into cellular $\mathrm{N}$-compounds and/or storage in vacuoles (Hawkesford et al., 2012). The $\mathrm{NO}_{3}^{-}$ stored in the vacuoles may be exported to compensate for the consumption of $\mathrm{NO}_{3}^{-}$in the metabolic pool (De Angeli et al., 2006), which suggests that vacuolar $\mathrm{NO}_{3}^{-}$may largely serve as $\mathrm{N}$ buffer for transport processes (Hawkesford et al., 2012). $\mathrm{NO}_{3}^{-}$/proton antiporters, which may be encoded by chloride channel family (CLC) genes, are responsible for $\mathrm{NO}_{3}^{-}$influx into plant vacuoles (Geelen et al., 2000). $\mathrm{NO}_{3}^{-}$transmembrane transporters may be expected to play a role after the uptake of exogenous $\mathrm{NO}_{2}$ or $\mathrm{NO}_{3}^{-}$ by the foliage. Several $\mathrm{NO}_{3}^{-}$transporters identified in leaves have been demonstrated to be closely correlated with e.g., stomatal opening (Guo et al., 2003), $\mathrm{NO}_{3}^{-}$reductase activity (Loqué et al., 2003), accumulation and remobilization of $\mathrm{NO}_{3}^{-}$(De Angeli et al., 2006; Fan et al., 2009; Lv et al., 2009). Thereby, such physiological processes may significantly influence and also be affected by the foliar uptake of $\mathrm{NO}_{2}$ or $\mathrm{NO}_{3}^{-}$.

Recently some $\mathrm{NO}_{3}^{-}$transporter genes were detected in leaves including several members of plant NRT1 family genes (e.g., AtNRT1.1, AtNRT1.4, AtNRT1.7, AtNRT1.11, and AtNRT1.12,.), NRT2 family genes (e.g., AtNRT2.1, AtNRT2.3, AtNRT2.4, AtNRT2.5, AtNRT2.6, AtNRT2.7, NpNRT2.1 and ZmNrt2.1.), and CLC family genes such as AtClCa and AtClCd (Orsel et al., 2002; Guo et al., 2003; Chopin et al., 2007; Fan et al., 2009; Hsu and Tsay, 2013) (Figure 1). These genes show various expression levels 

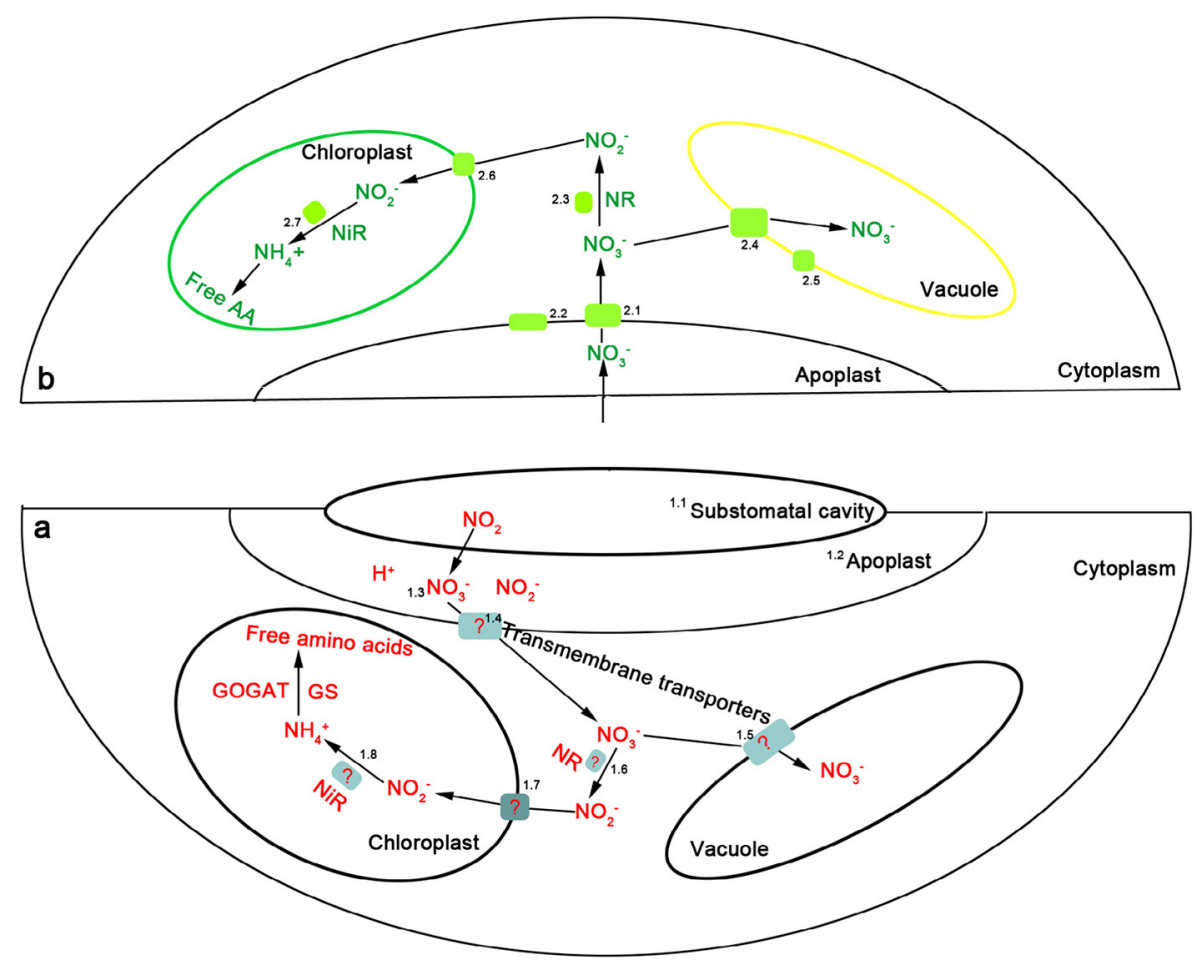

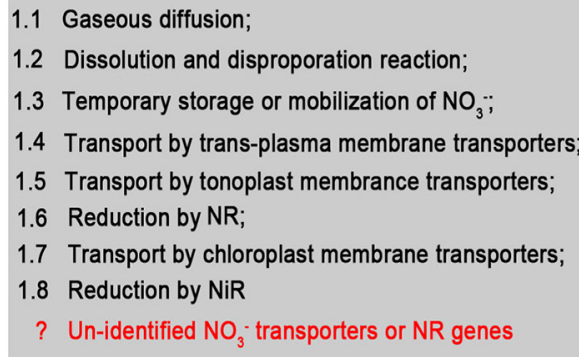

1.1 Gaseous diffusion;

1.2 Dissolution and disproporat

1.3 Temporary storage or mobilization of $\mathrm{NO}_{3}$.

1.5 Transport by tonoplast membrance transporters;

1.6 Reduction by NR;

.8 Reduction by NiR

Un-identified $\mathrm{NO}_{3}$ - transporters or NR genes

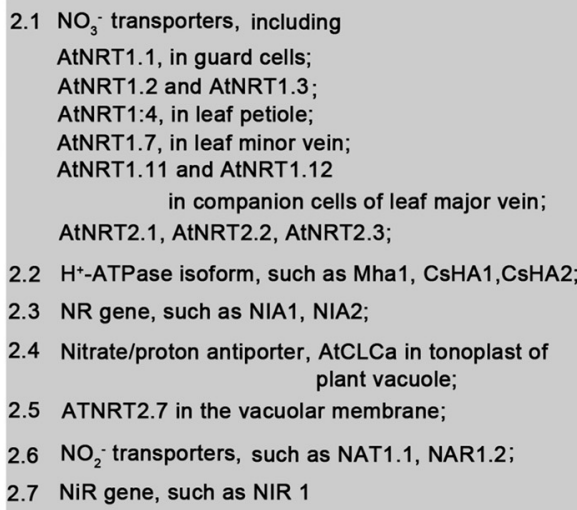

$2.1 \mathrm{NO}_{3}-$ transporters, including

AtNRT1.1, in guard cells;

leaf major vein;

2.2 $\mathrm{H}^{+}$-ATPase isoform, such as Mha1, CsHA1, CsHA2

2.3 NR gene, such as NIA1, NIA2

2.4 Nitrate/proton antiporter, AtCLCa in tonoplast of plant vacuole;

2.6 $\mathrm{NO}_{2}$ - transporters, such as NAT1.1, NAR1.2

2.7 NiR gene, such as NIR

FIGURE 1 | Nitrate $\left(\mathrm{NO}_{3}^{-}\right)$transporters and NR/NiR genes potentially involved after foliar uptake and assimilation of exogenous nitrogen dioxide $\left(\mathrm{NO}_{2}\right)(\mathrm{a}) / \mathrm{NO}_{3}^{-}(\mathrm{b})$.

in leaves and play diverse roles in regulating $\mathrm{NO}_{3}^{-}$metabolism (Hawkesford et al., 2012). For example, AtNRT1.1, a dual-affinity $\mathrm{NO}_{3}^{-}$-inducible transporter, showed a strong expression in guard cells and supports the stomatal function in the presence of $\mathrm{NO}_{3}^{-}$ (Guo et al., 2003). McNRT1, LeNRT1.1, and NpNRT1.1 were detected in the leaves of M. crystallinum, tomato and Nicotiana plumbaginifolia, respectively. McNRT1, sharing 60\% homology with the AtNRT1.1, was expressed in the mesophyll cells and cells adjacent to metaxylem vessels in the leaves (Popova et al., 2003). The gene plays potential roles in $\mathrm{NO}_{3}^{-}$uptake in the mesophyll cells, distribution and partitioning of $\mathrm{NO}_{3}^{-}$within the leaves. Moreover, AtNRT1.4 and AtNRT1.7 are of pure low-affinity transporters. AtNRT1.4 was expressed primarily in the leaf petiole
(Chiu et al., 2004). NRT1.7 mRNA was detected in the distal lamina of older leaves, but not in the roots (Fan et al., 2009). The two transporter genes participate in the process of leaf $\mathrm{NO}_{3}^{-}$ storage and remobilization. For the members of the NRT2 family, the amounts of AtNRT2.4 transcripts were predominant in leaves of the adult plants, followed by AtNRT2.5; the expression of AtNRT2.1, AtNRT2.6, and AtNRT2.7 were at low levels (Orsel et al., 2002). AtNRT2.1, AtNRT2.3, AtNRT2.4, and AtNRT2.5 are $\mathrm{NO}_{3}^{-}$-responsive genes, whereas AtNRT2.6 and AtNRT2.7 appear to be constitutive genes (Loqué et al., 2003). Particularly, AtNRT2.7 showed a strong leaf- and seed-specific expression pattern (Orsel et al., 2002; Chopin et al., 2007), while AtNRT2.3 was specifically expressed in leaves at a reproductive stage. 
Previous studies on foliar uptake of $\mathrm{NO}_{2}$ mainly focused on the deposition pathways, metabolic processes associated with $\mathrm{NO}_{2}$-derived $\mathrm{NO}_{3}^{-}$(Hu, 2011; Hu et al., 2014), and downstream products of $\mathrm{NO}_{2}-\mathrm{N}$ assimilation (Nussbaum et al., 1993; Weber et al., 1995). The current state of knowledge on the potential plant responses to $\mathrm{NO}_{2}$ exposure is summarized in Table 1 . However, the relationship between $\mathrm{NO}_{3}^{-}$transmembrane transporters and foliar $\mathrm{NO}_{2}$ uptake has received only limited scientific attention so far. Foliar uptake of $\mathrm{NO}_{2}$ seems to be species-specific and concentration-dependent ( $\mathrm{Hu}$ and Sun, 2010). Expression of the genes encoding leaf $\mathrm{NO}_{3}^{-}$transporters also appears to be species-specific (Ono et al., 2000; Orsel et al., 2002). The contribution of various expression patterns of transporter genes to species-specific $\mathrm{NO}_{2}$ uptake is currently unknown. Given the $\mathrm{N}$ transport mechanisms described above, a potential relationship between foliar $\mathrm{NO}_{2}$ uptake (substomatal build-up of $\mathrm{NO}_{2}$ and the subsequent reduction, storage, and remobilization of $\mathrm{NO}_{3}^{-}$) and $\mathrm{NO}_{3}^{-}$-responsive genes encoding the transmembrane transporters and $\mathrm{NO}_{3}^{-} / \mathrm{NO}_{2}^{-}$reductases may be hypothesized. For validating such hypothesis, future work focusing on the relationship between organ-specific expression of NRT1/NRT2 genes and species-specific $\mathrm{NO}_{2}$ uptake should be carried out.

\section{SUBSTOMATAL BUILD-UP OF NO 2 MAY DISTURB APOPLASTIC $\mathrm{pH}$ AND NO- TRANSPORTERS}

The apoplast is defined as the area within the plant tissues which is beyond the cell plasma membrane, and includes the cell wall, middle lamella, xylem and gas and water filled intercellular spaces (Sattelmacher, 2001). The leaf apoplastic space plays a role in ion exchange and as a diffusion barrier (Sattelmacher, 2001). Estimates of the volume of leaf water in the apoplast vary from 10 to $35 \%$ of total leaf water (Speer and Kaiser, 1991; Wardlaw, 2005). Dissolution of $\mathrm{NO}_{2}$ in the apoplast may produce $\mathrm{H}^{+}$and $\mathrm{NO}_{3}^{-} / \mathrm{NO}_{2}^{-}$. Foliar $\mathrm{NO}_{2}$ uptake is calculated to yield at most $0.22 \mathrm{~mol}$ excess $\mathrm{H}^{+}$per mol N (Raven, 1988). Therefore, a buildup of $\mathrm{NO}_{2}$ in the leaf substomatal cavities may lead to apoplastic $\mathrm{pH}$ disturbances. Among other factors, the resulting apoplastic $\mathrm{pH}$ changes will depend on $\mathrm{NO}_{2}$ concentration, root $\mathrm{N}$ supply and plant $\mathrm{N}$ status. The supply of $\mathrm{NO}_{3}^{-}$via the root system significantly increased the leaf apoplastic $\mathrm{pH}$ of Phaseolus vulgaris and Helianthus annuus, whereas the depletion of $\mathrm{NO}_{3}^{-}$in nutrient solution led to lower leaf apoplastic $\mathrm{pH}$ values in Zea mays (Mühling and Lauchli, 2001). $\mathrm{NH}_{4} \mathrm{NO}_{3}$ nutrition did not change the leaf apoplastic $\mathrm{pH}$ in sunflower (Kosegarten et al., 1999). Moreover, foliar $\mathrm{NH}_{4}^{+}$fertilization may either lead to apoplastic alkalinization (Felle and Hanstein, 2002) or acidification (Mühling and Lauchli, 2001). When supplying $\mathrm{NH}_{4} \mathrm{Cl}$ $(1 \mathrm{mM})$ via the root to soybean plants, low concentrations of $\mathrm{NO}_{2}\left(0.2-0.25 \mu \mathrm{L} \cdot \mathrm{L}^{-1}\right)$ significantly increased the leaf apoplastic $\mathrm{pH}$ (Qiao and Murray, 1997), whereas under a higher root $\mathrm{NO}_{3}^{-}$ dose $(5 \mathrm{mM})$, high concentrations of $\mathrm{NO}_{2}\left(1.1 \mu \mathrm{l} \cdot \mathrm{l}^{-1}\right)$ increased the acidity of the leaves (Qiao and Murray, 1998). Apoplastic $\mathrm{pH}$ is an important factor affecting plasmalemma proton pumps (Hoffmann et al., 1992; Sattelmacher, 2001). Apoplastic alkalinization or acidification may induce plasma membrane depolarization or hyperpolarization (Hedrich et al., 2001). This may further modulate the deactivation or activation of membrane-bound proton-transporting enzymes, and the corresponding ion channel regulation for co-transport of anions (Savchenko et al., 2000). Wippel et al. (2010) found that the fluctuation of apoplastic $\mathrm{pH}$ had a regulatory effect on plant sucrose transporters. Based on the above information, it can be reckoned that the apoplastic $\mathrm{pH}$ changes caused by $\mathrm{NO}_{2}$ may repress or induce $\mathrm{NO}_{3}^{-}$-responsive genes encoding the transmembrane transporters.

Some $\mathrm{NO}_{3}^{-}$transporter genes (such as AtNRT1.1 and $Z m N r t 2.1)$ in leaves are $\mathrm{NO}_{3}^{-}$-inducible, while others such as AtNRT2.5 are $\mathrm{NO}_{3}^{-}$-repressible (Okamoto et al., 2003). Lowaffinity transporter systems (NRT1 family) may significantly contribute to $\mathrm{NO}_{3}^{-}$uptake at external $\mathrm{NO}_{3}^{-}$concentrations above $250 \mu \mathrm{M}$. However, high-affinity transporters (NRT2 family) including the constitutive (cHATS $\mathrm{Km}=6-20 \mathrm{mM}$ ) and inducible HATS $(\mathrm{Km}=20-100 \mathrm{mM})$, are active at low external concentrations of $0-0.5 \mathrm{mM}$ (Crawford and Glass, 1998; Quaggiotti et al., 2003; Hawkesford et al., 2012). When analyzing the AtNRT1.7 $\mathrm{NO}_{3}^{-}$transporter gene in Arabidopsis, Fan et al. (2009) applied $50 \mathrm{mM} \mathrm{K}{ }^{15} \mathrm{NO}_{3}$ to carry out measurements on distal parts of the rosette leaf. The ${ }^{15} \mathrm{~N}-\mathrm{NO}_{3}^{-}$tracing assay showed that the percentage of total ${ }^{15} \mathrm{~N}$ in the leaves ranged from 0 to $10 \%$ for wild-type plants, and between 5 and $15 \%$ for the $n r t 1.7$ mutants. The percentage of $\mathrm{NO}_{3}^{-}-{ }^{15} \mathrm{~N}$ was in the range of the $\mathrm{NO}_{2}$-derived reduced $\mathrm{N}$ of wild herbaceous plants (from 0.98 to $10.1 \%)$ and woody plants $(0.15-12.7 \%)$ for the 217 taxa fumigated with $4.0 \pm 0.1 \mu \mathrm{mol} \cdot \mathrm{mol}^{-1} \mathrm{NO}_{2}$ (Morikawa et al., 1998). Accordingly, the content of $\mathrm{NO}_{2}$-derived reduced $\mathrm{N}$ ranged from 0.25 to $5.72 \mathrm{mg} \mathrm{N} \cdot \mathrm{g}^{-1}$ dry weight for wild herbaceous plants, and $0.04-6.57 \mathrm{mg} \mathrm{N} \cdot \mathrm{g}^{-1}$ dry weight for woody plants. This comparison suggests that the amounts of $\mathrm{NO}_{2}$-derived $\mathrm{NO}_{3}^{-}$in leaves are in the range of the $\mathrm{NO}_{3}^{-}$concentrations which may induce the two types of transporter systems (i.e., high and low affinity).

From the reasoning provided above, it can be reckoned that substomatal build-up of $\mathrm{NO}_{2}$ may lead to concentrationdependent changes of apoplastic $\mathrm{pH}$ and $\mathrm{NO}_{3}^{-}$concentration. Such pH fluctuations may influence $\mathrm{NO}_{3}^{-}$transmembrane transport by the induction or repression of the transporters and transporter gene expression, and may provide some sort of feedback regulation on the uptake of $\mathrm{NO}_{2}$ by the foliage. For example, apoplastic mesophyll signals have been recently found to induce rapid stomatal responses in Commelina communis (Fujita et al., 2013). In response to $\mathrm{NO}_{2}$ fumigation, multiple physiological and metabolic responses may occur which could either ultimately favor or inhibit the process of symplastic $\mathrm{N}$ uptake (Table 1). The multi-responses of $\mathrm{NO}_{3}^{-}$transporters to the substomatal build-up of $\mathrm{NO}_{2}$ may partially contribute to species-specific $\mathrm{NO}_{2}$ uptake, but future studies with different plant species shall be carried out for clarifying this complex issue.

\section{NITRATE TRANSPORTERS ARE POSSIBLY INVOLVED IN THE REDUCTION AND ACCUMULATION OF NO${ }_{2}$-DERIVED $\mathrm{NO}_{3}^{-}$}

In leaf cytoplasm, $\mathrm{NO}_{2}$-derived $\mathrm{NO}_{3}^{-}$has at least two fates: (i) assimilation into amino acids, and (ii) accumulation in vacuole (Hawkesford et al., 2012). The metabolic pathway will depend on the external $\mathrm{NO}_{3}^{-}$concentration and leaf $\mathrm{N}$ demand (Stulen et al., 1998). $\mathrm{NO}_{2}$-derived $\mathrm{NO}_{3}^{-}$will be assimilated mainly through the $\mathrm{NO}_{3}^{-}$assimilation pathway (Morikawa et al., 1998). $\mathrm{NO}_{3}^{-}$ 
Table 1 | Physiological and metabolic responses of plant organs to nitrogen dioxide $\left(\mathrm{NO}_{2}\right)$ exposure.

\begin{tabular}{|c|c|c|c|c|}
\hline Plant organ & Action site & \multicolumn{2}{|c|}{ Physiological function of exogenous $\mathrm{NO}_{2}$ on plants } & References \\
\hline & Apoplast & $\begin{array}{l}\text { Increase in the malondialdehyde (MDA) } \\
\text { level and superoxide dismutase (SOD) at } \\
0.5 \mu \mathrm{L} . \mathrm{L}^{-1} \mathrm{NO}_{2}^{[2.1]}\end{array}$ & $\begin{array}{l}\text { Acidity of apoplast }{ }^{[1.1]} ; \\
\text { Induced expression of germin-like proteins } \\
\text { (RmGLP2) }[2.2] ; \\
\text { Decline in MDA content and SOD } \\
\text { activity }{ }^{[2.3]} ; \\
\text { Decline in } \mathrm{ASA}^{[2.1]}\end{array}$ & $\begin{array}{l}{ }^{[2.1]} \text { Ma et al., 2007; } \\
{ }^{[2.2]} \text { Kondo et al., 2008; } \\
{ }^{[2.3]} \text { Chen et al., } 2010\end{array}$ \\
\hline & $\begin{array}{l}\text { Mitochondria/ } \\
\text { Peroxisome }\end{array}$ & & $\begin{array}{l}\text { Inhibition of dark respiration and apparent } \\
\text { photorespiration }{ }^{[3.1,4.2]} \\
\text { Protrusions from both plastids and } \\
\text { mitochondria of Phaseolus vulgaris } \\
\text { exposed to } \mathrm{NO}_{2}\left(10 \mathrm{ml}^{-I^{-1}}\right)^{[4.1]}\end{array}$ & 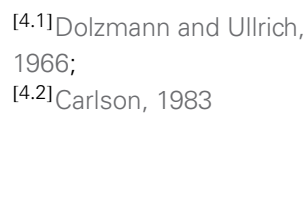 \\
\hline & $\begin{array}{l}\text { In developing } \\
\text { or maturing } \\
\text { leaves }\end{array}$ & $\begin{array}{l}\text { Increased leaf area }{ }^{[1.2]} \text {; } \\
\mathrm{NO}_{2}-\mathrm{N} \text { incorporation into free amino acids } \\
\text { such as Glu, Asp and } \mathrm{Gln}^{[3.4 ; 5.3]} \\
\text { Stimulation on cell proliferation and } \\
\text { enlargement as well as up-regulation of } \\
\text { the related genes, such as ARGOS, GRF5, } \\
\text { and } \mathrm{KLU}^{[5.4]}\end{array}$ & $\begin{array}{l}\mathrm{NO}_{2}-\mathrm{N} \text { incorporation into free amino acids } \\
\text { such as glutamine, glutamic acid, } \gamma \text {-amino } \\
\text { butyric acid and aspartic acid }{ }^{[5.1]} ; \\
\mathrm{NO}_{2} \text { led to swollen thylakoids and a } \\
\text { reduction in the number of grana } \\
\text { stacks }^{[5.2]}\end{array}$ & $\begin{array}{l}{ }^{[5.1]} \text { Yoneyama and } \\
\text { Sasakawa, 1979; } \\
{ }^{[5.2]} \text { Schiffgens-Gruber } \\
\text { and Lutz, } 1992 \\
{ }^{[5.3]} \text { Nussbaum et al., } \\
\text { 1993; } \\
{ }^{[5.4]} \text { Takahashi et al., } 2014\end{array}$ \\
\hline & Phloem & $\begin{array}{l}\mathrm{NO}_{2}-\mathrm{N} \text { incorporation into free amino acids } \\
\text { of bark of Norway spruce }\end{array}$ & $\begin{array}{l}\mathrm{NO}_{2}-\mathrm{N} \text { incorporation into free amino acids } \\
\text { such as serine, asparagine and } \\
\text { glutamine }{ }^{[6.2]}\end{array}$ & [6.2] Wellburn, 1990 \\
\hline Roots & & $\begin{array}{l}\mathrm{NO}_{2}-\mathrm{N} \text { incorporation into free amino acids } \\
\text { in Norway spruce roots }{ }^{[5.3]}\end{array}$ & 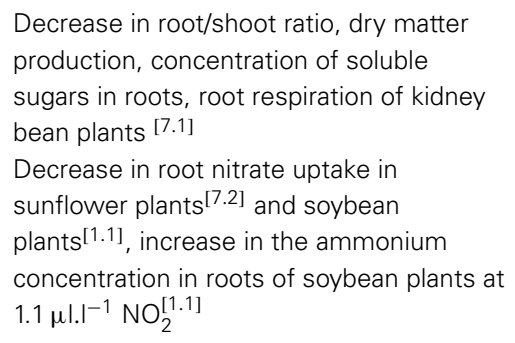 & $\begin{array}{l}{ }^{[7.1]} \text { |to et al., } 1985 ; \\
{ }^{[7.2]} \text { Okano et al., } 1985\end{array}$ \\
\hline
\end{tabular}


reductase (NR) is considered as a key rate-limiting enzyme of $\mathrm{NO}_{2}-\mathrm{N}$ assimilation (Hawkesford et al., 2012). A linear correlation was found between $\mathrm{NR}$ activity, $\mathrm{NO}_{2}$ concentration and amounts of $\mathrm{N}$ incorporated into amino acids (Sparks et al., 2001). However, high levels of $\mathrm{NO}_{2}$ fumigation resulted into a loss of NR activity or a rapid inactivation of the leaf NR (Takeuchi et al., 1985; Hisamatsu et al., 1988), and $\mathrm{NO}_{3}^{-}$accumulation (Ma et al., 2007). This down-regulation of the NR may be ascribed to at least one of the following phenomena: (i) a high $\mathrm{NO}_{2}$ concentration will inhibit the activities of glutamine synthetase and glutamate synthase, which leads to $\mathrm{NH}_{4}^{+}$accumulation and subsequently brings about a loss of NR activity (Orebamjo and Stewart, 1975; Padidam et al., 1991), and (ii) a high $\mathrm{NO}_{2}$-induced stomatal closure may lead to a rapid $\mathrm{NR}$ inactivation due to a low $\mathrm{CO}_{2}$ availability. High $\mathrm{NO}_{2}$ rapidly induced stomatal closure (Qiao and Murray, 1998). Stomatal closure may trigger a chain reaction wherein the lower $\mathrm{CO}_{2}$ availability will lead to the subsequent leaf NR activity decrease (Kaiser and Forster, 1989). NIA1 and NIA2 genes encode the two isoforms of the NR apoprotein (Wilkinson and Crawford, 1993). Recent reports show a close relationship between the expression of NIA1/NIA2 genes and NRT1/NRT2 genes. Addition of external $\mathrm{NO}_{3}^{-}$strongly induced the expression of genes encoding the NR (AtNIA1 and AtNIA2) and the transmembrane transporters (AtNRT1.1, AtNRT2.1, NpNRT2.1; Fraisier et al., 2001; Jonassen et al., 2009). In contrast, high levels of external $\mathrm{NO}_{3}^{-}$caused a down-regulation of AtNRT1.1 and AtNIA1 through a pathway of $\mathrm{NO}_{2}^{-}$-induced repression (Loqué et al., 2003). This downregulation of the AtNRT1.1 gene is associated with a decrease in the $\mathrm{NO}_{3}^{-}$influx. Earlier studies showed that high $\mathrm{NO}_{2}$ concentration fumigation under light or dark conditions resulted in leaf $\mathrm{NO}_{2}^{-}$accumulation (Yoneyama and Sasakawa, 1979; Yu et al., 1988). Thus, we may assume that a high $\mathrm{NO}_{2}$-caused $\mathrm{NO}_{2}^{-}$accumulation may lead to a negative feedback regulation on leaf $\mathrm{NO}_{2}$ uptake through the down-regulation of the NRT1.1 gene and the subsequent repression of the $\mathrm{NO}_{3}^{-}$influx. Moreover, studies on NR mutants showed that AtNRT1.1, AtNRT1.7, NpNRT2.1, and AtNIA1 are up-regulated in NR-deficient mutants (NIA2- and/or MoCo biosynthesis-deficient mutants) (Lejay et al., 1999; Vidmar et al., 2000; Fan et al., 2009). Under NR-repressible or -deficient conditions, this up-regulation of the transporter genes may be beneficial to an exportation of excess $\mathrm{NO}_{3}^{-}$in the leaf (Fan et al., 2009). Moreover, Jonassen et al. (2009) demonstrated that the bZIP transcription factors $H Y 5$ and $H Y H$ regulate positively NIA2 gene and negatively NRT1.1 gene. However, HY5 and HYH appear to be mediated by light but not by external $\mathrm{NO}_{3}^{-}$.

Excess $\mathrm{NO}_{3}^{-}$may be accumulated in leaf vacuole (Hawkesford et al., 2012). The $\mathrm{H}^{+} / \mathrm{NO}_{3}^{-}$antiport across tonoplast is responsible for $\mathrm{NO}_{3}^{-}$influx and $\mathrm{H}^{+} / \mathrm{NO}_{3}^{-}$symport for $\mathrm{NO}_{3}^{-}$efflux (Figure 1). The flux direction will depend on the requirements and conditions of the cell (Schumaker and Sze, 1987). Three members of the chloride channel family (CLC) genes AtClCa (De Angeli et al., 2006), AtClCc (Harada et al., 2004) and AtClCd (Lv et al., 2009) have been identified in the leaf tonoplast. De Angeli et al. (2009) demonstrated that adenosine triphosphate (ATP) induces a negative regulation on AtCLCa activity. $\mathrm{NO}_{2}$ fumigation significantly increased ATP amounts of Lolium perenne and Phleum pratense, the amounts increasing with raising $\mathrm{NO}_{2}$ concentrations (Wellburn et al., 1981). This may be due to the formation of free radicals in response to $\mathrm{NO}_{2}$ fumigation, which may damage photosynthetic membranes and hence alter the proton gradients to which ATP formation is linked (Wellburn et al., 1981). Yoneyama and Sasakawa (1979) found that 8 ppm $\mathrm{NO}_{2}$ fumigation under dark conditions resulted in $\mathrm{NO}_{2}^{-}$accumulation in spinach leaves. High doses of $\mathrm{NO}_{2}^{-}$resulted in the peroxidation of lipid constituents of chloroplastic membrane (Ezzine and Ghorbel, 2006). Chen et al. (2010) found that leaf uptake of $\mathrm{NO}_{2}$ reduced the rate of photosynthesis and increased the malondialdehyde (MDA) concentration, may be due to a competition for nicotinamide adenine dinucleotide phosphate (NADPH) between the processes of $\mathrm{NO}_{2}^{-}$reduction vs. carbon assimilation, and the generation of reactive oxygen species (ROS) (Sabaratnam and Gupat, 1988; Shimazaki et al., 1992).

\section{TRANSMEMBRANE TRANSPORTERS IN LEAVES MEDIATING $\mathrm{NO}_{3}^{-}$SIGNALING}

$\mathrm{NO}_{2}$ fumigation may significantly disrupt plant morphology and physiology by, for instance, changing the shoot to root ratio, stomatal, and gas exchange dynamics, or modifying root $\mathrm{N}$ uptake (Qiao and Murray, 1997, 1998; Table 1). The exposure of plants to $\mathrm{NO}_{2}$ increased the total content of soluble free amino acids in leaves and shoots (Nussbaum et al., 1993). Most of the amino acids may be used locally for the synthesis of e.g., Chlorophyll and Rubisco during rapid vegetative growth, or be ultimately designated for e.g., filling pods (Imsande and Touraine, 1994). $\mathrm{NO}_{3}^{-}$assimilation products (protein/nucleic acids and amino acids/amides) can also be transferred into roots under soil $\mathrm{N}$ deficit (Wellburn, 1990). Under a low $\mathrm{NO}_{3}^{-}$supply, gaseous $\mathrm{NO}_{2}$ may change the amino acid ratio of the xylem. For example, the amount of serine, asparagine and glutamine were high in the xylem of plants exposed to atmospheric $\mathrm{NO}_{2}$, whereas arginine, cysteine, valine and lysine were high in the control plants (Wellburn, 1990; Table 1). Moreover, $\mathrm{NO}_{2}$ treatment increased phloem transport of organic $\mathrm{N}$ and inhibited the rate of xylem $\mathrm{N}$ translocation.

$\mathrm{NO}_{2}-\mathrm{N}$ metabolism and the mobilization of metabolic products will trigger various signaling pathways that regulate the physiological and metabolic processes. The dissolution of $\mathrm{NO}_{2}$ and subsequent reduction can result in root $\mathrm{NO}_{3}^{-}$uptake changes. The xylem is part of leaf apoplast (Felle and Hanstein, 2002). Thus, $\mathrm{NO}_{2}$-caused apoplastic $\mathrm{pH}$ changes may serve as a signal to modify the uptake of $\mathrm{NO}_{3}^{-}$via the root system. This $\mathrm{NO}_{3}^{-}$signaling pathway has been explained by Qiao and Murray (1998). Moreover, $\mathrm{NO}_{3}^{-}$reduction can produce malate (Touraine et al., 1988); the organic acid needs to be membrane transported to be loaded into the phloem. A transport of malate from leaves to roots can serve as another signal to control root uptake of $\mathrm{NO}_{3}^{-}$(Touraine et al., 1992). This signaling pathway has been reported by Imsande and Touraine (1994). Tonoplast transport of malate plays an important role in physiological regulation in $\mathrm{NO}_{3}^{-}$nutrition (Hawkesford et al., 2012). At the cellular level, $\mathrm{NO}_{3}^{-}$accumulation led to increased expression of genes encoding organic acid synthesis (PPC, cytosolic PK, CS, ICDH-1) and accumulation of malate and a-oxoglutarat. In contrast, leaf 
malate supply can inhibit NIA expression, affecting both the NIA transcript level and the activity (Müller et al., 2001).

$\mathrm{NO}_{3}^{-}$itself may serve as a signaling molecule (Scheible et al., 1997). $\mathrm{NO}_{3}^{-}$addition to the growing media can induce or repress the expression of various genes encoding e.g., $\mathrm{NO}_{3}^{-}$transporters, $\mathrm{NO}_{3}^{-} / \mathrm{NO}_{2}^{-}$reductase, ferredoxin reductase, and the enzymes in the pentose phosphate pathway, or iron or sulfate transport and metabolism (Wang et al., 2003; Marschner, 2012). The expression of $\mathrm{NO}_{3}^{-}$-responsive genes [such as $\mathrm{NADH}$-specific and $\mathrm{NAD}(\mathrm{P}) \mathrm{H}$-bispecific $\mathrm{NR}$ genes] is dependent upon $\mathrm{NO}_{3}^{-}$flux but not on the $\mathrm{NO}_{3}^{-}$amount stored in the tissue (Gojon et al., 1991). Excess external $\mathrm{NO}_{3}^{-}$may be stored in several vacuoles and recirculated after storage (Hawkesford et al., 2012). $\mathrm{NO}_{3}^{-}$ remobilization may occur among different organs, for instance, from older leaves to younger leaves during the vegetative stage or from leaves to seeds during the reproductive stage (Schiltz et al., 2005; Hawkesford et al., 2012). N remobilization is rate-limited by the transport of $\mathrm{NO}_{3}^{-}$across tonoplast of vacuole, plasma membrane of mesophyll cell, plasma membrane of companion cell and sieve element, and phloem loading (Fan et al., 2009). CLC genes (AtClCa, $A t C l C c$, and $A t C l C d$ ) are required for the transport of $\mathrm{NO}_{3}^{-}$across tonoplast in vacuole. Disruption of one of these genes will influence the flux of $\mathrm{NO}_{3}^{-}$in vacuoles (De Angeli et al., 2006). AtNRT2.4 showed a strong induction in a low $\mathrm{NO}_{3}^{-}$provision. Orsel et al. (2004) suggested that AtNRT2.4 and AtNRT2.5 participate in the transport of $\mathrm{NO}_{3}^{-}$from stored pools (vacuoles) to cytoplasm. Moreover, AtNRT2.7 was also involved in this type of $\mathrm{NO}_{3}^{-}$flux; this gene could play roles in leaf balance between the amount of $\mathrm{NO}_{3}^{-}$used for assimilation and that re-absorbed for further transport (Orsel et al., 2002). Four NRT1 family genes (AtNRT1.4, AtNRT1.7, AtNRT1.11, and AtNRT1.12) participate in the phloem- and/or xylem-loading of $\mathrm{NO}_{3}^{-}$(Figure 1). AtNRT1.4 was expressed predominantly in the leaf petiole and involved in petiole $\mathrm{NO}_{3}^{-}$accumulation (Chiu et al., 2004). The mutation of the AtNRT1:4 resulted in significant changes of $\mathrm{NO}_{3}^{-}$content in leaf petiole and the lamina. Furthermore, the deficiency of AtNRT1.4 can alter leaf development. NRT1.7 was expressed in the phloem of the leaf minor vein and mediated the remobilization of excess $\mathrm{NO}_{3}^{-}$from older leaves to younger leaves (Fan et al., 2009). Compared with the wild-type plants, the nrt1.7 null mutants accumulated a higher amount of $\mathrm{NO}_{3}^{-}$in the older leaves and decreased the $\mathrm{NO}_{3}^{-}$content of phloem exudates from older leaves. The newly identified $\mathrm{NO}_{3}^{-}$transporters (NRT1.11 and NRT1.12) were expressed in the companion cells of the major vein (Hsu and Tsay, 2013). They play roles in xylem-to-phloem transfer for redistributing $\mathrm{NO}_{3}^{-}$into developing leaves. Moreover, several NRT2 genes may also be involved in the $\mathrm{N}$ remobilization. For example, $\mathrm{ZmNrt2.1}$ plays a potential role in $\mathrm{NO}_{3}^{-}$loading from the xylem or in its compartmentation (Quaggiotti et al., 2003).

\section{CONCLUSION}

The substomatal build-up of $\mathrm{NO}_{2}$ and subsequent $\mathrm{NO}_{3}^{-}$ metabolism may lead to apoplastic alkalinization or acidification and to $\mathrm{NO}_{3}^{-} / \mathrm{NO}_{2}^{-}$concentration fluctuations in the leaf apoplast and symplast (e.g., cytoplasm and vacuole), which depend on $\mathrm{NO}_{2}$ concentration and root $\mathrm{N}$ supply. These changes will cause complex responses of $\mathrm{NO}_{3}^{-}$-responsive genes encoding $\mathrm{NO}_{3}^{-}$transporters and $\mathrm{NO}_{3}^{-} / \mathrm{NO}_{2}^{-}$reductase. For example, addition of external $\mathrm{NO}_{3}^{-}$produced a strong induction on NR genes (such as AtNIA1 and AtNIA2) and the transporter genes (such as AtNRT1.1, AtNRT2.1, and NpNRT2.1). However, excess $\mathrm{NO}_{2}^{-}$significant inhibited the expression of AtNRT1.1 and AtNIA1, and disturbed CLC family genes by regulating the generation of ATP. This down-regulation of the NRT1.1 gene is associated with a decrease in $\mathrm{NO}_{3}^{-}$influx. Moreover, AtNRT2.4, AtNRT2.5, and AtNRT2.7 may participate in the transfer of $\mathrm{NO}_{3}^{-}$ from stored pools (vacuoles) to cytoplasm. AtNRT1.4, AtNRT1.7, AtNRT1.11, and AtNRT1.12 are involved in the phloem- and/or xylem-loading of $\mathrm{NO}_{3}^{-}$. Thus, these genes are suggested to play rate-limiting roles in foliar uptake of $\mathrm{NO}_{2}$. Further work is proposed to investigate the relationship between organ specificity of NRT1/NRT2 gene expression and species-specific $\mathrm{NO}_{2}$ uptake.

In practical terms, a high rate of low concentration $\mathrm{NO}_{2}$ absorption by the foliage may be positive for preserving an adequate plant $\mathrm{N}$ status. However, a high $\mathrm{NO}_{2}$ concentration may alter leaf apoplast chemistry, leading to the accumulation of $\mathrm{NO}_{3}^{-}$ and $\mathrm{NO}_{2}^{-}$, and providing signals which may negatively affect plant $\mathrm{N}$ nutrition. These factors are however closely linked with leaf $\mathrm{NO}_{3}^{-}$transporters and may also interact with the foliar uptake processes (e.g., by promoting stomatal closure). Thereby, a low $\mathrm{NO}_{2}$ concentration may act as a positive regulation signal (Takahashi et al., 2014) by stimulating the leaf $\mathrm{NO}_{3}^{-}$transporters, and enhancing $\mathrm{NO}_{3}^{-}$transport and distribution. In contrast, a high $\mathrm{NO}_{2}$ concentration in relation to a high rate of foliar $\mathrm{NO}_{2}$ absorption, may repress the expression of $\mathrm{NO}_{3}^{-}$transporters and enzymes, which may protect the cells or organelles from $\mathrm{NO}_{2}$ damage.

\section{AUTHOR CONTRIBUTIONS}

Yanbo $\mathrm{Hu}$ organized and wrote the original manuscript; Yanbo $\mathrm{Hu}$ and Victoria Fernandez discussed and revised the revising manuscript and approved the final version; Ling Ma collected the information for Table 1, and went through the manuscript.

\section{ACKNOWLEDGMENTS}

This work was supported by grants from "Fundamental Research Funds for the Central Universities" (Grant No. 2572014CA24, DL10BB24) and "National Natural Science Foundation" (Grant No. 31300506).

\section{REFERENCES}

Bertoni, G. (2012). A nitrate transporter for both roots and shoots. Plant Cell 24, 1. doi: 10.1105/tpc.112.240110

Carlson, R. W. (1983). Interaction between $\mathrm{SO}_{2}$ and $\mathrm{NO}_{2}$ and their effects on photosynthetic properties of soybean Glycine max. Environ. Pollut. Ecol. Biol. 32, 11-38. doi: 10.1016/0143-1471(83)90071-5

Chen, Z. M., Chen, Y. X., Du, G. J., Wu, X. L., and Li, F. (2010). Effects of 60 day $\mathrm{NO}_{2}$ fumigation on growth, oxidative stress and antioxidative response in Cinnamomum camphora seedlings. J. Zhejiang Univ. Sci. B 11, 190-199. doi: 10.1631/jzus.B0910350

Chiu, C. C., Lin, C. S., Hsia, A. P., Su, R. C., Lin, H. L., and Tsay, Y. F. (2004). Mutation of a nitrate transporter, AtNRT1:4, results in a reduced petiole nitrate content and altered leaf development. Plant Cell Physiol. 45, 1139-1148. doi: $10.1093 / \mathrm{pcp} / \mathrm{pch} 143$ 
Chopin, F., Orsel, M., Dorbe, M. F., Chardon, F., Truong, H. N., Miller, A. J., et al. (2007). The Arabidopsis AtNRT2.7 nitrate transporter controls nitrate content in seeds. Plant Cell 19, 1590-1602. doi: 10.1105/tpc.107. 050542

Crawford, N. M., and Glass, A. D. M. (1998). Molecular and physiological aspects of nitrate uptake in plants. Trends Plant Sci. 10, 389-395. doi: 10.1016/S13601385(98)01311-9

De Angeli, A., Monachello, D., Ephritikhine, G., Frachisse, J. M., Thomine, S., Gambale, F., et al. (2006). The nitrate/proton antiporter AtCLCa mediates nitrate accumulation in plant vacuoles. Nature 442, 939-942. doi: 10.1038/nature05013

De Angeli, A., Moran, O., Wege, S., Filleur, S., Ephritikhine, G., Thomine, S., et al. (2009). ATP binding to the C terminus of the Arabidopsis thaliana nitrate/proton antiporter, AtCLCa, regulates nitrate transport into plant vacuoles. J. Biol. Chem. 284, 26526-26532. doi: 10.1074/jbc.M109.005132

Dolzmann, P., and Ullrich, H. (1966). Einige Beobachtungen iiber Beziehungen zwischen Chloroplasten und Mitchondrien im Palisadenparenchym von Phaseolus vulgaris. Zeitschrift fiir Pflanzenphysiologie 55, 165-180.

Eastham, A. M., and Ormrod, D. P. (1986). Visible injury and growth responses of young cuttings of Populus Canadensis and P. nigra to nitrogen dioxide and sulphur dioxide. Can J. For. Res. 16, 1289-1292. doi: 10.1139/x86-228

Eichert, T., and Fernández, V. (2012). "Uptake and release of elements by leaves and other aerial plant parts," in Marschner's Mineral Nutrition of Higher Plants, ed P. Marschner (Oxford: Academic Press), 71-84.

Ezzine, M., and Ghorbel, M. H. (2006). Physiological and biochemical responses resulting from nitrite accumulation in tomato. (Lycopersicon esculentum Mill. cv. Ibiza F1). J. Plant Physiol. 163, 1032-1039. doi: 10.1016/j.jplph.2005.07.013

Fan, S. C., Lin, C. S., Hsu, P. K., Lin, S. H., and Tsay, Y. F. (2009). The Arabidopsis nitrate transporter NRT1.7, expressed in phloem, is responsible for source-to-sink remobilization of nitrate. Plant Cell 21, 2750-2761. doi: 10.1105/tpc.109.067603

Felle, H. H., and Hanstein, S. (2002). The apoplastic $\mathrm{pH}$ of the substomatal cavity of Vicia faba leaves and its regulation responding to different stress factors. J. Exp. Bot. 53, 73-82. doi: 10.1093/jexbot/53.366.73

Fernández, V., and Brown, P. H. (2013). From plant surface to plant metabolism: the uncertain fate of foliar-applied nutrients. Front. Plant Sci. 4:289. doi: 10.3389/fpls.2013.00289

Fraisier, V., Dorbe, M. F., and Daniel-Vedele, F. (2001). Identification and expression analyses of two genes encoding putative low-affinity nitrate transporters from Nicotiana plumbaginifolia. Plant Mol. Biol. 45, 181-190. doi: 10.1023/A:1006426616760

Fujita, T., Noguchi, K., and Terashima, I. (2013). Apoplastic mesophyll signals induce rapid stomatal responses to $\mathrm{CO}_{2}$ in Commelinacommunis. New Phytol. 199, 395-406. doi: 10.1111/nph.12261

Geelen, D., Lurin, C., Bouchez, D., Frachisse, J. M., Lelièvre, F., Courtial, B., et al. (2000). Disruption of putative anion channel gene AtCLC-a in Arabidopsis suggests a role in the regulation of nitrate content. Plant J. 21, 259-267. doi: 10.1046/j.1365-313x.2000.00680.x

Gojon, A., Wakrim, R., Passama, L., and Robin, P. (1991). Regulation of $\mathrm{NO}_{3}^{--}$ assimilation by anion availability in excised soybean leaves. Plant Physiol. 96, 398-405. doi: 10.1104/pp.96.2.398

Guo, F. Q., Young, J., and Crawford, N. M. (2003). The nitrate transporter AtNRT1.1 (CHL1) functions in stomatal opening and contributes to drought susceptibility in Arabidopsis. Plant Cell 15, 107-117. doi: 10.1105/tpc.006312

Harada, H., Kuromori, T., Hirayama, T., Shinozaki, K., and Leigh, R. A. (2004). Quantitative trait loci analysis of nitrate storage in Arabidopsis leading to an investigation of the contribution of the anion channel gene, AtCLC-c, to variation in nitrate levels. J. Exp. Bot. 55, 2005-2014. doi: 10.1093/jxb/ erh224

Hawkesford, M., Horst, W., Kichey, T., Lambers, H., Schjoerring, J., Skrumsager, I., et al. (2012). "Functions of Macronutrients," in Marschner's Mineral Nutrition of Higher Plants, 3rd Edn., eds P. Marschner (London: Elsevier), 135-178.

Hedrich, R., Neimainis, S., Savchenko, G., Felle, H. H., Kaiser, W. M., and Heber, U. (2001). Changes in apoplastic $\mathrm{pH}$ and membrane potential in leaves in relation to stomatal responses to $\mathrm{CO}_{2}$, malate, abscisic acid or interruption of water supply. Planta 213, 594-601. doi: 10.1007/s004250100524

Hisamatsu, S., Nihira, J., Takeuchi, Y. C., Satoh, S., and Kondo, N. (1988). $\mathrm{NO}_{2}$ suppression of light-induced nitrate reductase in squash cotyledons. Plant Cell Physiol. 29, 395-401.
Hoffmann, B., Plänker, R., and Mengel, K. (1992). Measurements of pH in the apoplast of sunflower leaves by means of fluorescence. Physiol. Plant. 84, 146-153. doi: 10.1111/j.1399-3054.1992.tb08777.x

Hsu, P. K., and Tsay, Y. F. (2013). Two phloem nitrate transporters, NRT1.11 and NRT1.12, are important for redistributing xylem-borne nitrate to enhance plant growth. Plant Physiol. 163, 844-856. doi: 10.1104/pp.113.226563

$\mathrm{Hu}$, Y. B. (2011). $\mathrm{NO}_{2}$-drived $\mathrm{NO}_{3}^{-}$metabolism in leaves. Insci. J. 1, 90-101. doi: 10.5640 /insc. 010290

Hu, Y. B., Bellaloui, N., Sun, G. Y., Tigabu, M., and Wang, J. H. (2014). Exogenous sodium sulfide improves morphological and physiological responses of a hybrid Populus species to nitrogen dioxide. J. Plant Physiol. 171, 868-875. doi: 10.1016/j.jplph.2013.10.018

Hu, Y. B., and Sun, G. Y. (2010). Leaf nitrogen dioxide uptake coupling apoplastic chemistry, carbon/sulfur assimilation, and plant nitrogen status. Plant Cell Rep. 29, 1069-1077. doi: 10.1007/s00299-010-0898-5

Imsande, J., and Touraine, B. (1994). $\mathrm{N}$ demand and the regulation of nitrate uptake. Plant Physiol. 105, 3-7.

Ito, O., Okano, K., Kuroiwa, M., and Totsuka, T. (1985). Effects of $\mathrm{NO}_{2}$ and $\mathrm{O}_{3}$ alone or in combination on kidney bean plants (Phaseolus vulgaris L.): partitioning of assimilates and root activities. J. Exp. Bot. 36, 652-662. doi: 10.1093/jxb/36.4.652

Jonassen, E. M., Sevin, D. C., and Lillo, C. (2009). The bZIP transcription factors HY5 and HYH are positive regulators of the main nitrate reductase gene in Arabidopsis leaves, NIA2, but negative regulators of the nitrate uptake gene NRT1.1. J. Plant Physiol. 166, 2071-2076. doi: 10.1016/j.jplph.2009. 05.010

Kaiser, W. M., and Forster, J. (1989). Low $\mathrm{CO}_{2}$ prevents nitrate reduction in leaves. Plant Physiol. 91, 970-974. doi: 10.1104/pp.91.3.970

Kondo, K., Yamada, K., Nakagawa, A., Takahashi, M., Morikawa, H., and Sakamoto, A. (2008). Molecular characterization of atmospheric $\mathrm{NO}_{2}$-responsive germinlike proteins in azalea leaves. Biochem. Biophys. Res. Commun. 377, 857-861. doi: 10.1016/j.bbrc.2008.10.060

Kosegarten, H. U., Hoffmann, B., and Mengel, K. (1999). Apoplastic pH and $\mathrm{Fe}^{3+}$ reduction in intact sunflower leaves. Plant Physiol. 121, 1069-1079. doi: 10.1104/pp.121.4.1069

Lejay, L., Tillard, P., Lepetit, M., Olive, F. D., Filleur, S., Daniel-Vedele, F., et al. (1999). Molecular and functional regulation of two $\mathrm{NO}_{3}^{-}$uptake systems by Nand C-status of Arabidopsis plants. Plant J. 18, 509-519. doi: 10.1046/j.1365313X.1999.00480.x

Loqué, D., Tillard, P., Gojon, A., and Lepetit, M. (2003). Gene expression of the $\mathrm{NO}_{3}^{-}$transporter NRT1.1 and the nitrate reductase NIA1 is repressed in Arabidopsis roots by $\mathrm{NO}_{2}^{-}$, the product of $\mathrm{NO}_{3}^{-}$reduction. Plant Physiol. 132, 958-967. doi: 10.1104/pp.102.018523

Lv, Q. D., Tang, R. J., Liu, H., Gao, X. S., Li, Y. Z., Zheng, H. Q., et al. (2009). Cloning and molecular analyses of the Arabidopsis thaliana chloride channel gene family. Plant Sci. 176, 650-661. doi: 10.1016/j.plantsci.2009. 02.006

Ma, C. Y., Xu, X., Hao, L., and Cao, J. (2007). Nitrogen dioxide-induced responses in Brassica campestris seedlings: the role of hydrogen peroxide in the modulation of antioxidative level and induced resistance. Agric. Sci. China 6, 1193-1200. doi: 10.1016/S1671-2927(07)60163-1

Marschner, P. (2012). Mineral Nutrition of Higher Plants. San Diego, CA: Academic Press.

Morikawa, H., Higaki, A., Nohno, M., Takahashi, M., Kamada, M., Nakata, M., et al. (1998). More than a 600-fold variation in nitrogen dioxide assimilation among 217 plant taxa. Plant Cell Environ. 21, 180-190. doi: 10.1046/j.13653040.1998.00255.x

Mühling, K. H., and Lauchli, A. (2001). Influence of chemical form and concentration of nitrogen on apoplastic $\mathrm{pH}$ of leaves. J. Plant Nutr. 25, 399-411. doi: 10.1081/PLN-100104968

Müller, C., Scheible, W. R., Stitt, M., and Krapp, A. (2001). Influence of malate and 2-oxoglutarate on the NIA transcript level and nitrate reductase activity in tobacco leaves. Plant Cell Environ. 24, 191-203. doi: 10.1111/j.13653040.2001.00664.x

Murray, F., Wilson, S., and Samaraweera, S. (1994). $\mathrm{NO}_{2}$ increases wheat grain yield even in the presence of $\mathrm{SO}_{2}$. Agric. Ecosyst. Environ. 48, 115-123. doi: 10.1016/0167-8809(94)90082-5

Nussbaum, S., Ballmoos, P. V., Gfeller, H., Schlunegger, U. P., Fuhrer, J., Rhodes, D., et al. (1993). Incorporation of atmospheric ${ }^{15} \mathrm{NO}_{2}$-nitrogen into free amino 
acids by Norway spruce Picea abies (L.) Karst. Oecologia 94, 408-414. doi: 10.1007/BF00317117

Okamoto, M., Vidmar, J. J., and Glass, A. D. (2003). Regulation of NRT1 and NRT2 gene families of Arabidopsis thaliana: responses to nitrate provision. Plant Cell Physiol. 44, 304-317. doi: 10.1093/pcp/pcg036

Okano, K., Totsuka, T., Fukuzawa, T., and Tazakl, T. (1985). Growth responses of plants to various concentrations of nitrogen dioxide. Environ. Pollut. 38, 361-373. doi: 10.1016/0143-1471(85)90107-2

Ono, F., Frommer, W. B., and von Wire'n, N. (2000). Coordinated diurnal regulation of low- and high-affinity nitrate transporters in tomato. Plant Biol. 2, 17-23. doi: 10.1055/s-2000-297

Orebamjo, T. O., and Stewart, G. R. (1975). Ammonium inactivation of nitrate reductase in Lemna minor L. Planta 122, 37-44. doi: 10.1007/BF003 85402

Orsel, M., Eulenburg, K., Krapp, A., and Daniel-Vedele, F. (2004). Disruption of the nitrate transporter genes AtNRT2.1 and AtNRT2.2 restricts growth at low external nitrate concentration. Planta 219, 714-721. doi: 10.1007/s00425-0041266-x

Orsel, M., Krapp, A., and Daniel-Vedele, F. (2002). Analysis of the NRT2 nitrate transporter family in Arabidopsis: structure and gene expression. Plant Physiol. 129, 886-896. doi: 10.1104/pp.005280

Padidam, M., Venkateswarlu, K., and Johri, M. M. (1991). Ammonium represses NADPH nitrate reductase in the moss Funaria hygrometrica. Plant Sci. 75, 185-194. doi: 10.1016/0168-9452(91)90233-X

Popova, O. V., Dietz, K. J., and Golldack, D. (2003). Salt-dependent expression of a nitrate transporter and two amino acid transporter genes in Mesembryanthemum crystallinum. Plant Mol. Biol. 52, 569-578. doi: 10.1023/A:1024802101057

Qiao, Z., and Murray, F. (1997). Effects of atmospheric nitrogen dioxide on uptake and assimilation of ammonium in soybean plants. J. Plant Nutr. 20, 1183-1190. doi: 10.1080/01904169709365326

Qiao, Z., and Murray, F. (1998). The effects of $\mathrm{NO}_{2}$ on the uptake and assimilation of nitrate by soybean plants. Environ. Exp. Bot. 10, 33-40. doi: 10.1016/S00988472(97)00023-3

Quaggiotti, S., Ruperti, B., Borsa, P., Destro, T., and Malagoli, M. (2003). Expression of a putative high-affinity $\mathrm{NO}_{3}^{-}$transporter and of an $\mathrm{H}^{+}$-ATPase in relation to whole plant nitrate transport physiology in two maize genotypes differently responsive to low nitrogen availability. J. Exp. Bot. 54, 1023-1031. doi: $10.1093 /$ jxb/erg106

Raven, J. A. (1988). Acquisition of nitrogen by the shoots of land plants: its occurrence and implication for acid-base regulation. New Phytol. 109, 1-20. doi: 10.1111/j.1469-8137.1988.tb00212.x

Sabaratnam, S., and Gupat, G. (1988). Effects of nitrogen dioxide on biochemical and physiological characteristics of soybean. Environ. Pollut. 55, 149-158. doi: 10.1016/0269-7491(88)90125-X

Sattelmacher, B. (2001). The apoplast and its significance for plant mineral nutrition. New Phytol. 149, 167-192. doi: 10.1046/j.1469-8137.2001.00034.x

Savchenko, G., Wiese, C., Neimanis, S., Hedrich, R., and Heber, U. (2000). pH regulation in apoplastic and cytoplasmic cell compartments of leaves. Planta 211, 246-255. doi: 10.1007/s004250000280

Scheible, W. R., Gonzalez-Fontes, A., Lauerer, M., Muller-Rober, B., Caboche, M., and Stitt, M. (1997). Nitrate acts as a signal to induce organic acid metabolism and repress starch metabolism in tobacco. Plant Cell 9, 783-798. doi: $10.1105 /$ tpc.9.5.783

Schiffgens-Gruber, A., and Lutz, C. (1992). Ultrastructure of mesophyll cell chloroplasts of spruce needles exposed to $\mathrm{O}_{3}, \mathrm{SO}_{2}$ and $\mathrm{NO}_{2}$ alone and in combination. Environ. Exp. Bot. 32, 243-254. doi: 10.1016/0098-8472(92)9 0007-O

Schiltz, S., Munier-Jolain, N., Jeudy, C., Burstin, J., and Salon, C. (2005). Dynamics of exogenous nitrogen partitioning and nitrogen remobilization from vegetative organs in pea revealed by ${ }^{15} \mathrm{~N}$ in vivo labeling throughout seed filling. Plant Physiol. 137, 1463-1473. doi: 10.1104/pp.104. 056713

Schmutz, P., Tarjan, D., Günthardt-Goerg, M. S., Matyssek, R., and Bucher, J. B. (1995). Nitrogen dioxide- a gaseous fertilizer of Poplar trees. Phyton 35, 219-232.

Schumaker, K. S., and Sze, H. (1987). Decrease of $\mathrm{pH}$ gradients in tonoplast vesicles by $\mathrm{NO}_{3}^{-}$and $\mathrm{Cl}^{-}$: evidence for $\mathrm{H}^{+}$-coupled anion transport. Plant Physiol. 83, 490-496. doi: 10.1104/pp.83.3.490
Shimazaki, K., Yu, S. W., Sakaki, T., and Tanaka, K. (1992). Differences between spinach and kidney bean plants in terms of sensitivity to fumigation with $\mathrm{NO}_{2}$. Plant Cell Physiol. 33, 267-273.

Siegwolf, R. T. W., Matyssek, R., Saurer, M., Maurer, S., Günthardt-Goerg, M. S., Schmutz, P., et al. (2001). Stable isotope analysis reveals differential effects of soil nitrogen and nitrogen dioxide on the water use efficiency in hybrid poplar leaves. New Phytol. 149, 233-246. doi: 10.1046/j.1469-8137.2001. 00032.x

Sparks, J. P., Monson, R. K., Sparks, K. L., and Lerdau, M. (2001). Leaf uptake of nitrogen dioxide $\left(\mathrm{NO}_{2}\right)$ in a tropical wet forest: implications for tropospheric chemistry. Oecologia 127, 214-221. doi: 10.1007/s004420000594

Speer, M., and Kaiser, W. M. (1991). Ion relations of symplastic and apoplastic space in leaves from Spinacia oleracea L. and Pisum sativum L. under salinity. Plant Physiol. 97, 990-997. doi: 10.1104/pp.97.3.990

Srivastava, H. S., Jolliffe, P. A., and Runeckles, V. C. (1974). Inhibition of gas exchange in bean leaves by $\mathrm{NO}_{2}$. Can. J. Bot. 53, 466-474. doi: 10.1139/ b75-057

Stiegler, J. C., Richardson, M. D., and Karcher, D. E. (2011). Foliar nitrogen uptake following urea application to putting green turfgrass species. Crop Sci. 51, 1253-1260. doi: 10.2135/cropsci2010.06.0377

Stulen, I., Perez-Soba, M., De Kok, L. J., and Van Der Eerden, L. (1998). Impact of gaseous nitrogen deposition on plant functioning. New Phytol. 139, 61-70 doi: 10.1046/j.1469-8137.1998.00179.x

Takagi, M., and Gyokusen, K. (2004). Light and atmospheric pollution affect photosynthesis of street trees in urban environments. Urban For. Urban Green. 2, 167-171. doi: 10.1078/1618-8667-00033

Takahashi, M., Furuhashi, T., Ishikawa, N., Horiguchi, G., Sakamoto, A., Tsukaya, H., et al. (2014). Nitrogen dioxide regulates organ growth by controlling cell proliferation and enlargement in Arabidopsis. New Phytol. 201, 1304-1315. doi: 10.1111/nph.12609

Takahashi, M., Sakamoto, A., Ezura, H., and Morikawa, H. (2011). Prolonged exposure to atmospheric nitrogen dioxide increases fruit yield of tomato plants. Plant Biotechnol. 8, 485-487. doi: 10.5511/plantbiotechnology.11. 0819a

Takeuchi, Y. C., Nihira, J., Kondo, N., and Tezuka, T. (1985). Change in Nitratereducing activity in squash seedlings with $\mathrm{NO}_{2}$ fumigation. Plant Cell Physiol. 26, 1027-1035.

Touraine, B., Grignon, N., and Grignon, C. (1988). Charge balance in $\mathrm{NO}_{3}^{--}$ fed soybean: estimation of $\mathrm{K}^{+}$and carboxylate recirculation. Plant Physiol. 88, 605-612. doi: 10.1104/pp.88.3.605

Touraine, B., Muller, B., and Grignon, C. (1992). Effect of phloem-translocated malate on $\mathrm{NO}_{3}^{-}$uptake by roots of intact soybean plants. Plant Physiol. 99, 1118-1123. doi: 10.1104/pp.99.3.1118

Uscola, M., Villar-Salvador, P., Oliet, J., and Warren, C. (2014). Foliar absorption and root translocation of nitrogen from different chemical forms in seedlings of two Mediterranean trees. Environ. Exp. Bot. 104, 34-43. doi: 10.1016/j.envexpbot.2014.03.004

Vidmar, J. J., Zhuo, D., Siddiqi, M. Y., Schjoerring, J. K., Touraine, B., and Glass, A. D. M. (2000). Regulation of high-affinity nitrate transporter genes and highaffinity nitrate influx by nitrogen pools in roots of barley. Plant Physiol. 123, 307-318. doi: 10.1104/pp.123.1.307

Wang, R. C., Okamoto, M., Xing, X., and Crawford, N. M. (2003). Microarray analysis of the nitrate response in Arabidopsis roots and shoots reveals over 1000 rapidly responding genes and new linkages to glucose, trehalose-6phosphate, iron, and sulfate metabolism. Plant Physiol. 132, 556-567. doi: 10.1104/pp.103.021253

Wardlaw, I. F. (2005). Viewpoint: consideration of apoplastic water in plant organs: a reminder. Funct. Plant Biol. 32, 561-569. doi: 10.1071/FP04127

Weber, P., Nussbaum, S., Fuhrer, J., Gfeller, H., Schlunegger, U. P., Brunold, C., et al. (1995). Uptake of atmospheric ${ }^{15} \mathrm{NO}_{2}$ and its incorporation into free amino acids in wheat (Triticum aestivum L.). Physiol. Plant 94, 71-77. doi: 10.1111/j.1399-3054.1995.tb00786.x

Wellburn, A. R. (1990). Why are atmospheric oxides of nitrogen usually phytotoxic and not alternative fertilizers? New Phytol. 115, 395-429. doi: 10.1111/j.14698137.1990.tb00467.x

Wellburn, A. R., Higginson, C., Robinson, D., and Walmsley, C. (1981). Biochemical explanations of more than additive inhibitory effects of low atmospheric levels of sulphur dioxide plus nitrogen dioxide upon plants. New Phytol. 88, 223-237. doi: 10.1111/j.1469-8137.1981.tb01719.x 
Wilkinson, J. Q., and Crawford, N. M. (1993). Identification and characterization of a chlorate-resistant mutant of Arabidopsis thaliana with mutations in both nitrate reductase structural genes NIA1 and NIA2. Mol. Gen. Genet. 239, 289-297.

Wippel, K., Wittek, A., Hedrich, R., and Sauer, N. (2010). Inverse pH regulation of plant and fungal sucrose transporters: a mechanism to regulate competition for sucrose at the host/pathogen interface? PLOS ONE 5:e12429. doi: 10.1371/journal.pone.0012429

Yoneyama, T., and Sasakawa, H. (1979). Transformation of atmospheric $\mathrm{NO}_{2}$ absorbed in spinach leaves. Plant Cell Physiol. 20, 263-266.

Yoneyama, T., Sasakawa, H., Ishizuka, S., and Totsuka, T. (1979). Absorption of atmospheric $\mathrm{NO}_{2}$ by plants and soils. Soil Sci. Plant Nutr. 25, 267-275. doi: 10.1080/00380768.1979.10433167

Yu, S. W., Li, L., and Shimazaki, K. I. (1988). Response of spinach and kidney bean plants to nitrogen dioxide. Environ. Pollut. 55, 1-13. doi: 10.1016/02697491(88)90155-8
Conflict of Interest Statement: The authors declare that the research was conducted in the absence of any commercial or financial relationships that could be construed as a potential conflict of interest.

Received: 28 March 2014; accepted: 04 July 2014; published online: 30 July 2014. Citation: Hu Y, Fernández V and Ma L (2014) Nitrate transporters in leaves and their potential roles in foliar uptake of nitrogen dioxide. Front. Plant Sci. 5:360. doi: $10.3389 / \mathrm{fpls} .2014 .00360$

This article was submitted to Crop Science and Horticulture, a section of the journal Frontiers in Plant Science.

Copyright (c) $2014 \mathrm{Hu}$, Fernández and Ma. This is an open-access article distributed under the terms of the Creative Commons Attribution License (CC BY). The use, distribution or reproduction in other forums is permitted, provided the original author(s) or licensor are credited and that the original publication in this journal is cited, in accordance with accepted academic practice. No use, distribution or reproduction is permitted which does not comply with these terms. 